\title{
Analysis of Peak Power Capacity on Rooftop Solar PV 1.25 kWp at Sun Conditions 90 Degrees
}

\author{
Habib Satria* \\ Dept. Of Electrical Engineering \\ Faculty of Engineering \\ University of Medan Area \\ habib.satria@staff.uma.ac.id
}

\author{
Syafii \\ Dept. Of Electrical Engineering \\ Faculty of Engineering \\ Andalas University \\ syafii@ft.unand.ac.id
}

\author{
Aswardi \\ Dept. Of Electrical Engineering \\ Faculty of Engineering \\ University of Padang \\ aswardi@ft.unp.ac.id
}

*Corresponding author: habib satria,habib.satria@staff.uma.ac.id

\begin{abstract}
This paper describes the optimization of energy conversion when solar radiation occurs at peak power conditions, namely at 11.00 am to $2.00 \mathrm{pm}$ where the position of the sun is parallel to the layout of the PV Rooftop installation. The panels used are 5 units with the type of polycrystalline with a capacity of 1 panel unit consisting of $250 \mathrm{Wp}$. The position of the panels installed on the roof of the Andalas University building is based on an angle of $90^{\circ}$ degrees with a position of $\pm 255 \mathrm{~m}$ above sea level. The advantages obtained when placed on the roof of the building are due to the minimal impact of shadow effects and environmental disturbances. Data retrieval using DC current and voltage sensors is then connected to the Arduino Uno microcontroller which is then interfaced in graphic form. Considerations in the installation of $P V$ by reviewing the weather conditions at that time where the conditions were sunny and the air was clean with the aim that the performance when solar radiation entered the solar cells could be produced more optimally. Based on the data obtained at peak power, PV can convert DC power to $972.56 \mathrm{Wp}$. In the final stage of collecting data recorded on this $\mathrm{PC}$, it can later be used as a reference for installing solar panels for household electricity scales in the West Sumatra region.
\end{abstract}

Keywords-Arduino Uno, Rooftop PV, Weather Conditions.

\section{INTRODUCTION}

The high intensity of sunlight in the territory of Indonesia opens up enormous opportunities in the development and development of renewable energy today. The trend of using renewable energy around the world is currently growing rapidly, especially with the advantage of being able to reduce carbon emissions [1][2]. The opportunity for the Indonesian state to implement renewable energy is eagerly awaited because there are still many rural areas that have not fully experienced electrical energy from the grid network [3]. One of the most popular renewable energies used today is the installation of PV[4][5][6]. This system works by converting solar radiation directly into electrical energy with the help of solar cells [7][8][9]. West Sumatra is an area traversed by the equator and has a very high tropical climate [10][11]. Based on BMKG data, solar radiation reaches 12 hours per day, this can be the first step in investing in the installation of solar panels independently[12]. The most efficient installation is by building Roof PV above housing or buildings. In addition to being able to optimize land, the advantages of installing Rooftop PV are that it can reduce the effects of shadows and disturbances from the surrounding nature [13][14][15]. There are several types of solar panels that can be installed on the roof, one of which is the polycrystalline type. Empirical studies that have been carried out in various countries around the world prove that PV installation will have a positive impact on the 4.0 industrial revolution[16][17]. Therefore, it is necessary to conduct research on the installation of PV by analogizing the construction of PV in the form of a home scale. PV data collection is carried out in sunny conditions with the aim of seeing the maximum performance of the PV. Then the type of inverter used is a grid tie inverter where this tool does not require a battery as a backup. In this test, PV is connected in series using polycrystalline PV with a PV capacity of $1.25 \mathrm{kWp}$. After all the components are integrated with each other, the ACS712 and ZMPT101B sensors are used which have been connected to the Arduino Uno microcontroller to record DC power. The data is taken by looking at the maximum peak power that can be converted to $\mathrm{PV}$ at a flat position where the sun is around 11.00 am to 2.00 $\mathrm{pm}$. This time interval represents the maximum PV performance and peak load [18]. In addition, the DHT11 sensor is used to monitor the condition of the panel surface temperature and also the humidity of the surrounding air. The data retrieval time is set using a 5 minute delay so that when the data is recorded it can reduce the occurrence of data loss. The data recorded on the PC will be visualized in the form of graphs. In order to make it easier to analyze later, the data will be processed using Microsoft Excel and the data can later be used as a reference in PV development in the West Sumatra area.

\section{Methodology}

The model used in this research is to integrate several PV components that are connected to the inverter and then the inverter with DC power will be converted into AC power before entering the load. Some of the important components seen in fig 1 are PV, Inverter and load. In selecting the inverter, the Grid Inverter type is used which is mutually integrated between DC and Grid power. Therefore a backup of the battery is not needed. The data is recorded using a 
voltage sensor and a DC current sensor and then connected to the Arduino Uno microcontroller. In the final stage, the data stored on the PC is then displayed in a visual graph.

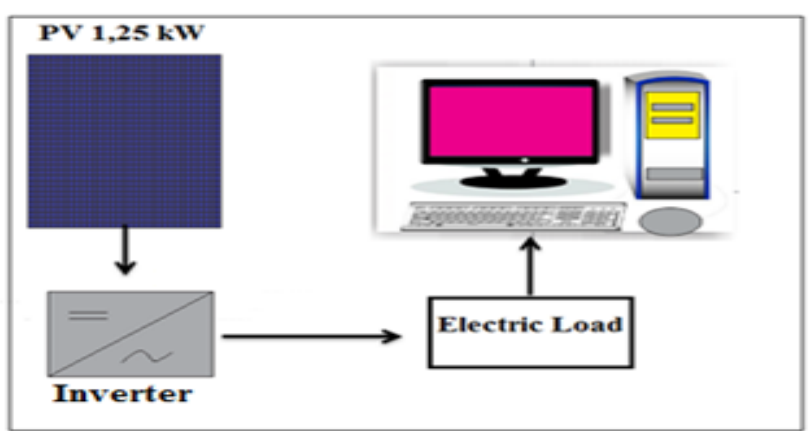

Fig 1. PV design connected to PC

\section{A. Time Location and Data Collection}

Photovoltaic Module at the Department of Electrical Engineering, Andalas University, Padang. This station is located at coordinates $0^{\circ} 54^{\prime} 51^{\prime \prime S} 100^{\circ} 27^{\prime} 51^{\prime \prime E} 5 \mathrm{~km}$, at an altitude of $303 \mathrm{~m}$ above sea level. Fig 2 shows the research location indicated by google earth.

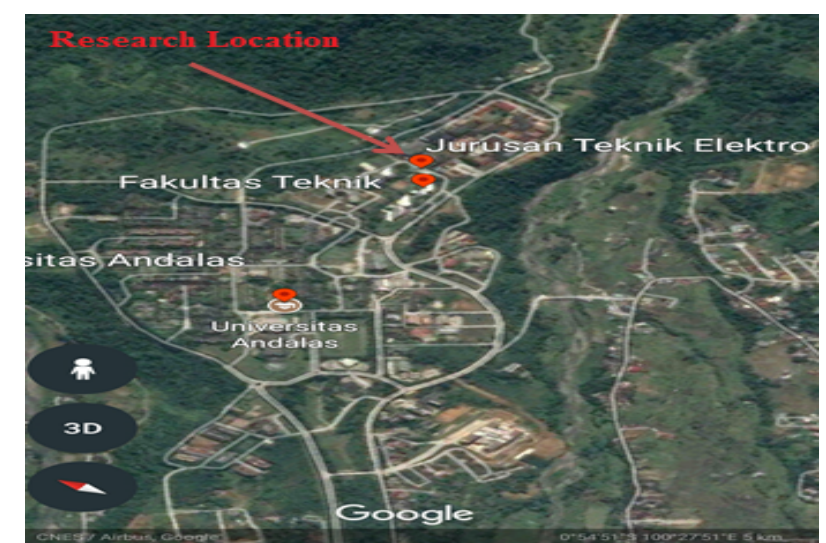

Fig 2. Rooftop PV Data Collection Location

\section{B. PV Power Plant Conversion Process}

Components of solar cells consist of photovoltaic or commonly abbreviated PV whose function is to produce electrical energy from light intensity. Basically, solar cells are silicon (Si) materials.[19]. With the presence of diodes in solar cells and the occurrence of $p-n$ junctions, sunlight can produce electrical energy. Solar cells consist of a $\mathrm{p}$ - and ntype semiconductor material junction ( $p-n$ junction semiconductor) which, when exposed to sunlight, will flow electrons, this flow of electrons is referred to as the flow of electric current. [20][21]. When the light intensity decreases (cloudy, cloudy or rainy) the electric current generated is also reduced, and expanding solar panels means increasing solar power conversion. For an illustration of the working principle of a solar cell, consider the following Fig 3.

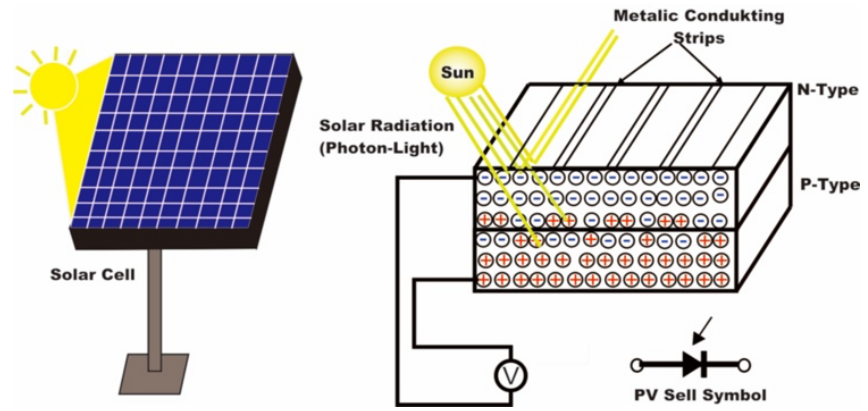

Fig.3 Solar Energy conversion process to PV

\section{Equivalent Circuit}

Solar cell equivalent circuit is very necessary to know the parameters of solar panels and as a mathematical modeling in the circuit. The equivalent circuit of a solar cell consists of a photocurrent $\left(\mathrm{I}_{\mathrm{ph}}\right)$, a diode, series resistance $\left(\mathrm{R}_{\mathrm{s}}\right)$ and parallel resistance $\left(R_{\text {sh }}\right)$, as shown in Fig. 4.

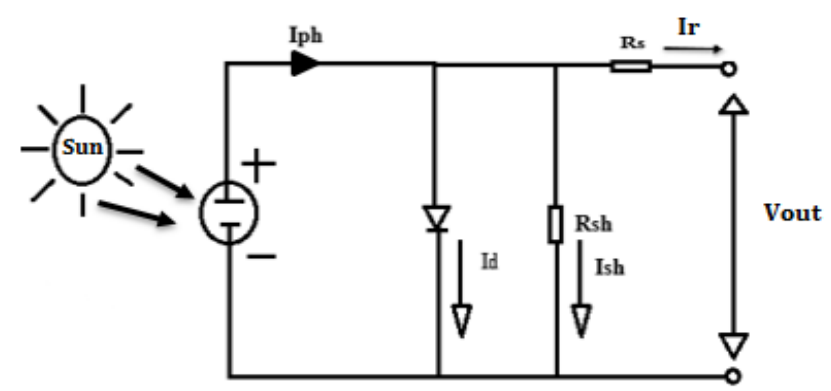

Fig 4. Rooftop PV Data Collection Location

Where:

Iph $\quad=$ PV cell current $(\mathrm{A})$

Vout $=$ PV cell voltage $(\mathrm{V})$

Ir $\quad=$ Current generated by the PV cell (A)

Id $\quad=$ Reverse saturation current (A)

Ish $=$ Short circuit current (A)

$\mathrm{n} \quad=$ ideal diode factor (value 1 for ideal diode)

$\mathrm{q}=$ Electron filling $(1.602 \times 10-19 \mathrm{C})$

$\mathrm{k}=$ Boltzman constant $(1.3806 \times 10-23 \mathrm{~J} . \mathrm{K}-1)$

$\mathrm{T}=\mathrm{PV}$ cell temperature $(\mathrm{K})$

$\mathrm{T} 1=\mathrm{PV}$ cell reference temperature $(2980 \mathrm{~K})$

Rs $\quad=$ Series resistance $(\Omega)$

Rsh $=$ Parallel resistance $(\Omega)$

$\mathrm{KO}=$ Current temperature coefficient $(\% / \mathrm{oK})$

\section{PV Power Plant Installation}

Installation of PV on the campus of the Faculty of Engineering, Andalas University, which is $\pm 255 \mathrm{~m}$. The PV power plant is built on the roof with the aim of reducing the effects of shading and interference from nature. Polycrystalline type PV has a capacity of $250 \mathrm{Wp}$ where in total there is $1.25 \mathrm{kWp}$. For installation in series by synchronizing with the capacity of the grid tie inverter. The following Fig 5 Roof PV installation. 


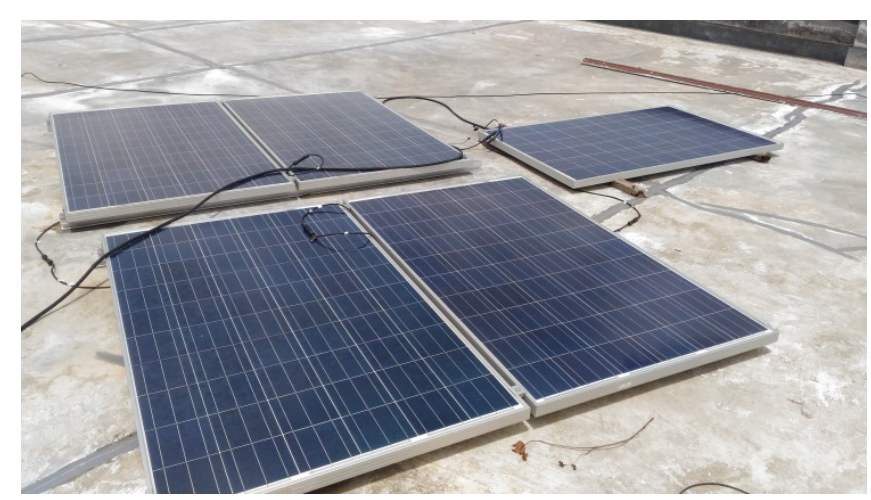

Fig 5. Rooftop PV Installation Capacity $1.25 \mathrm{kWp}$

After installing the PV, then the DC power is connected to the inverter which has the ability to convert DC electrical energy to AC electrical energy. The circuit model can be seen in Figure 6 below.

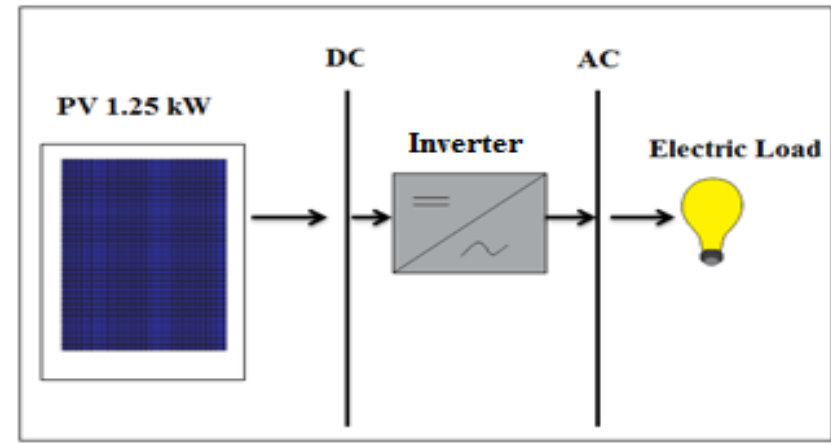

Fig 6. Simple off-grid Photovoltaic model

\section{E. Temperature and Humidity Sensor}

The DHT11 sensor functions to sense objects in the form of temperature and humidity objects, meaning that this sensor can measure two parameters at once. The DHT11 sensor has the advantage of excellent sensing data reading quality, responsiveness and not easily interfered with. This sensor also has a feature for calibration of the humidity calibration chamber, and its calibration is accurate enough for monitoring the surface of the solar panel. The specifications are shown in table 1 below.

TABLE 1. SPECIFICATIONS OF TEMPERATURE/HUMIDITY SENSORS

\begin{tabular}{|c|c|}
\hline \multicolumn{2}{|c|}{ Characteristics } \\
\hline Power Supply & DC $3.5-5.5 \mathrm{~V}$ \\
\hline Current Consumption & Measurement $0,3 \mathrm{~mA}$, standby \\
& $60 \mu \mathrm{A}$ \\
\hline Sampling Period & Lebih dari 2 detik \\
\hline \multicolumn{2}{|c|}{ Air humidity measurement } \\
\hline Measurement Resolution & $16 \mathrm{Bit}$ \\
\hline Repeatability & $25^{\circ} \mathrm{C} \pm 5 \% \mathrm{RH}$ \\
\hline Measurement Accuracy & Fully Interchangeble \\
\hline Interchangeability & $1 / 2(63 \%)$ of $25^{\circ} \mathrm{C} 6$ detik \\
\hline Response Time & $< \pm 0.3 \% \mathrm{RH}$ \\
\hline Hysterical & $< \pm 0.5 \% \mathrm{RH} / \mathrm{yr}$ in \\
\hline Long term stability & $16 \mathrm{Bit}$ \\
\hline \multicolumn{2}{|c|}{ Temperature Measurement } \\
\hline Measurement Resolution & $\mathrm{At} 25^{\circ} \mathrm{C} \pm 2^{\circ} \mathrm{C}$ \\
\hline Repeatability & $1 / \mathrm{e}(63 \%) 10$ detik \\
\hline Range &
\end{tabular}

The temperature characteristics of the PV output have previously been tested on PV in a laboratory environment with 3 temperature variables by getting the results of room temperature measurements in $45{ }^{\circ} \mathrm{C}$ conditions will produce a current rating of $35{ }^{\circ} \mathrm{C}$ then $35{ }^{\circ} \mathrm{C}$ temperature will get a current rating that is more than $25{ }^{\circ} \mathrm{C}[22]$.

\section{F. Digital Light Meter}

To measure the intensity of sunlight and regulate the amount of incoming light, a digital light meter is needed. Digital light meter used with model TASI-8731 as Fig 7.

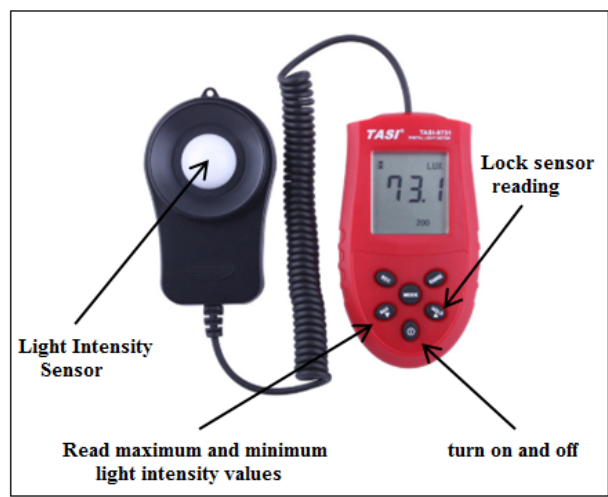

Fig 7. Physical Form and Important Functions of Digital Meter

The use of this component helps to see the intensity of sunlight under various conditions such as sunny, cloudy and cloudy conditions. In this study, data collection was carried out to see the intensity of sunlight when it was hot, which was in the time range from $11.00 \mathrm{am}$ to $2.00 \mathrm{pm}$.

\section{Result AND Discussion}

In this study, we will discuss the optimization and efficiency of energy produced by solar panels by analogizing a capacity of $1.25 \mathrm{kWp}$ or household scale load. The acquisition system by looking at the energy conversion at 11.00 am to $2.00 \mathrm{pm}$. Monitoring uses current sensors and voltage sensors that are connected using Arduino and several other devices. To see the component integration can be seen in fig 8 .

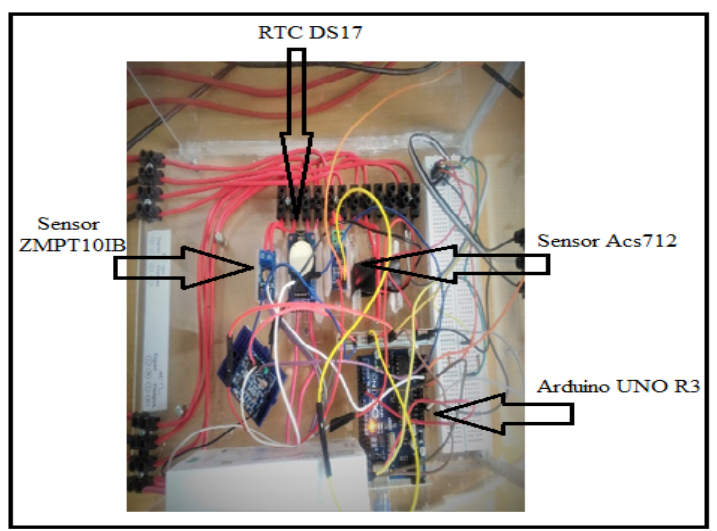

Fig 8. Arduino Integration with Sensor

\section{A. Data Collection}

Data collection is carried out in sunny weather. From the data generated, accurate information will be obtained and determine the efficiency of PV by calculating the electrical 
load used. Data retrieval was carried out for 3 hours, namely when the peak power was between 11.00 am to $2.00 \mathrm{pm}$. The amount of electrical power that can be generated by PLTS can be calculated using the results of measuring voltage multiplied by current. While the amount of electrical power that can be generated by PV is calculated using equation (1) below:

$$
\sum \mathrm{Wh}=\sum(\mathrm{P} \times \mathrm{t})
$$

To find out the total energy over a certain period of time will be calculated using equation (2).

$$
\text { Energy }=\int_{0}^{t} p(\text { time }) d t
$$

\section{B. Data Analysis}

Data analysis for bright data recorded by a PC in settings uses a delay of about 5 minutes later to analyze the data to make it easier to process and convert it to a table at a delay of 15 minutes as listed in table 2 .

TABLE II: MEASUREMENT RESULTS ON SUNNY WEATHER CONDITIONS AND PEAK POWER

\begin{tabular}{|c|c|c|c|c|c|}
\hline Time & $\begin{array}{c}\text { Temperature } \\
(\boldsymbol{C} \text { C) }\end{array}$ & $\begin{array}{c}\text { Humidity } \\
(\%)\end{array}$ & $\begin{array}{c}\text { DC } \\
\text { Volt }\end{array}$ & $\begin{array}{c}\text { AC } \\
\text { Current }\end{array}$ & $\begin{array}{c}\text { DC } \\
\text { Power }\end{array}$ \\
\hline $11: 00$ & 29 & 65 & 122 & 4.73 & 576.9 \\
\hline $11: 15$ & 30 & 66 & 123 & 5.43 & 667.44 \\
\hline $11: 30$ & 30 & 68 & 125 & 5.81 & 726.74 \\
\hline $11: 45$ & 30 & 65 & 123 & 6.59 & 810.47 \\
\hline $12: 00$ & 31 & 64 & 124 & 7.29 & 903.57 \\
\hline $12: 15$ & 31 & 63 & 123 & 7.91 & 972.56 \\
\hline $12: 30$ & 31 & 67 & 124 & 7.44 & 922.79 \\
\hline $12: 45$ & 31 & 67 & 122 & 7.75 & 945.74 \\
\hline $13: 00$ & 31 & 65 & 122 & 7.05 & 860.62 \\
\hline $13: 15$ & 31 & 64 & 122 & 7.21 & 879.53 \\
\hline $13: 30$ & 31 & 67 & 122 & 5.89 & 718.76 \\
\hline $13: 45$ & 30 & 67 & 121 & 5.35 & 647.21 \\
\hline $14: 00$ & 30 & 64 & 120 & 4.26 & 511.63 \\
\hline
\end{tabular}

Based on table 3 which consists of output panel surface temperature data, humidity, DC voltage, DC current and DC power, it can be seen that the maximum energy conversion on roof PV with a capacity of $1.25 \mathrm{kWp}$ occurs at $12.15 \mathrm{am}$ with the peak power generated reaching $972.56 \mathrm{Wp}$.

\section{Output Data Weather Conditions}

The data collection process for sunny conditions is carried out when the sun's position is $90 \mathrm{o}$ on the panel surface. Text and graphic data obtained is the result of data from recording information using integrated sensors that work with each other with good accuracy.

TABLE III: TEST RESULTS OF DIGITAL LIGHT METER DURING SUNNY WEATHER CONDITIONS

\begin{tabular}{|c|c|l|}
\hline Time & $\begin{array}{c}\text { Sunlight Intensity } \\
\text { (Lux) }\end{array}$ & Weather \\
\hline $11: 00 \mathrm{am}-12: 00 \mathrm{pm}$ & 137100 & Sunny \\
\hline $12: 00 \mathrm{am}-01: 00 \mathrm{pm}$ & 144900 & Sunny \\
\hline $01: 00 \mathrm{pm}-02: 00 \mathrm{pm}$ & 132400 & Sunny \\
\hline
\end{tabular}

To determine the intensity of sunlight, a Digital Light Meter is used. The measurement results in sunny conditions can be seen in Table 3.

\section{Panel Surface Temperature Output Data Graph}

The following data is displayed in the form of a graph of the surface temperature of the solar cell in sunny weather conditions during the time range from 11.00 am to $2.00 \mathrm{pm}$. Based on fig 9 the temperature in the hot sun weather conditions that occurred at $12.15 \mathrm{pm}$ reached a temperature of $31^{\circ} \mathrm{C}$.

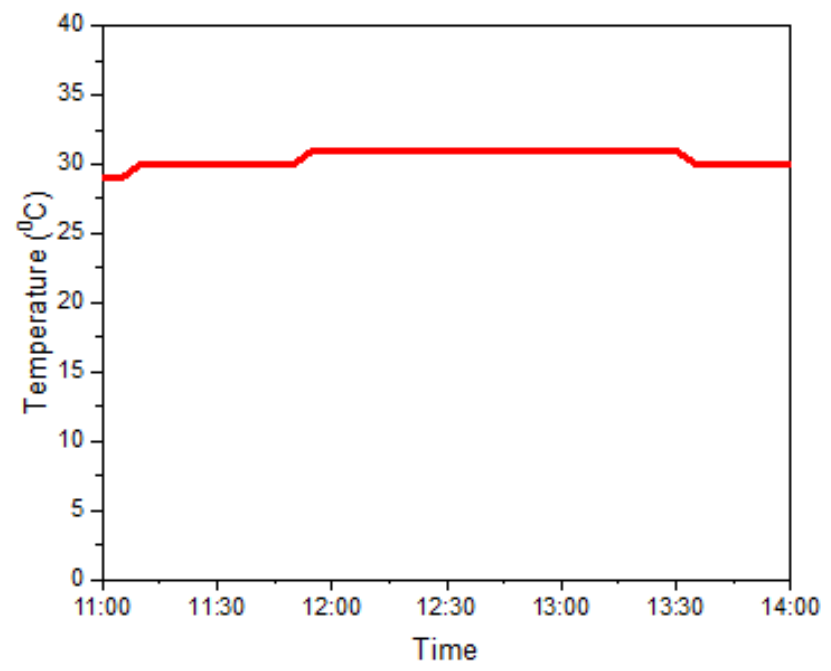

Fig 9. Temperature measurement with graphic display

\section{E. Humidity Data Output}

Based on fig 10, recorded data for air humidity measurements in clean weather conditions using the DHT11 sensor when peak power is at 12.15 pm by $63 \%$.

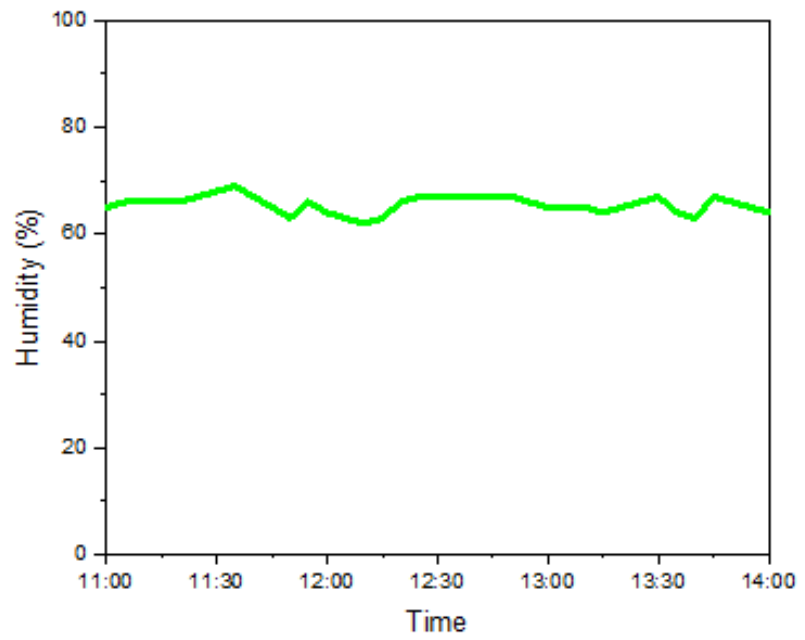

Fig 10. Humidity measurement with graphic display

\section{F. DC Voltage Output Data}

In DC measurements, there is a fluctuating voltage fluctuation, this can be seen on the display in the form of a DC voltage graph in hot sun conditions during the time span that occurs. The measurement results at peak power at 12.15 pm obtained a DC voltage of 123 Volts. The voltage rating 
during measurement continues to obtain a DC voltage of $120 \mathrm{~V}$. During the monitoring time there are some fluctuations, depending on weather conditions that change in a short time so that the output voltage on the PV shows irregularity. This can be seen in the monitoring in fig 11

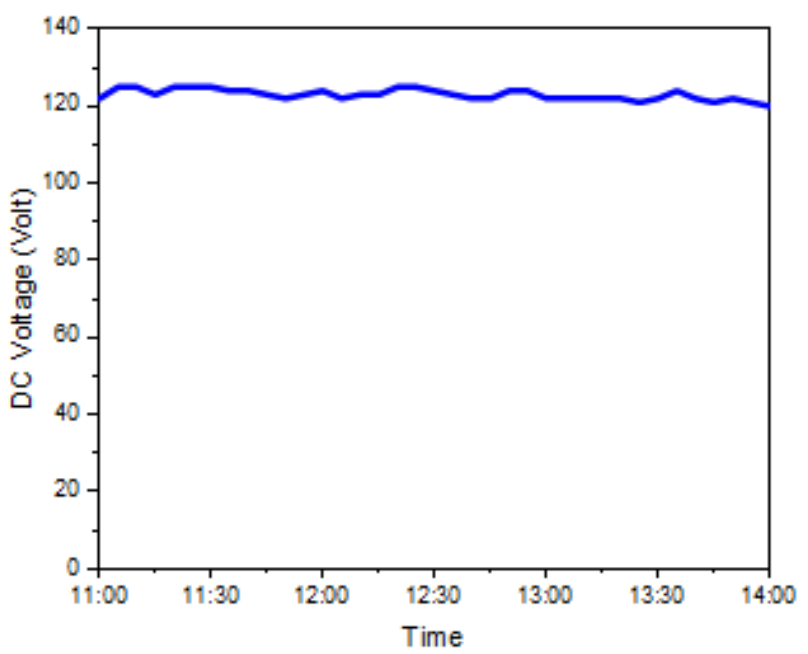

Fig 11. DC voltage measurement with graphic display

\section{G. Output data DC Current}

Graphic display of DC current at peak power is quite high reaching 7.91. At 11.30 am the current began to fluctuate irregularly due to the use of different loads due to the activity of using electrical energy consumption. Hot sun weather conditions help PV to optimize energy conversion from the sun so that the current rating is almost at its maximum. However, at $1.30 \mathrm{pm}$ the current began to decline. This situation is caused by the sun's rays away from the panel surface. This can be seen in Figure 2.

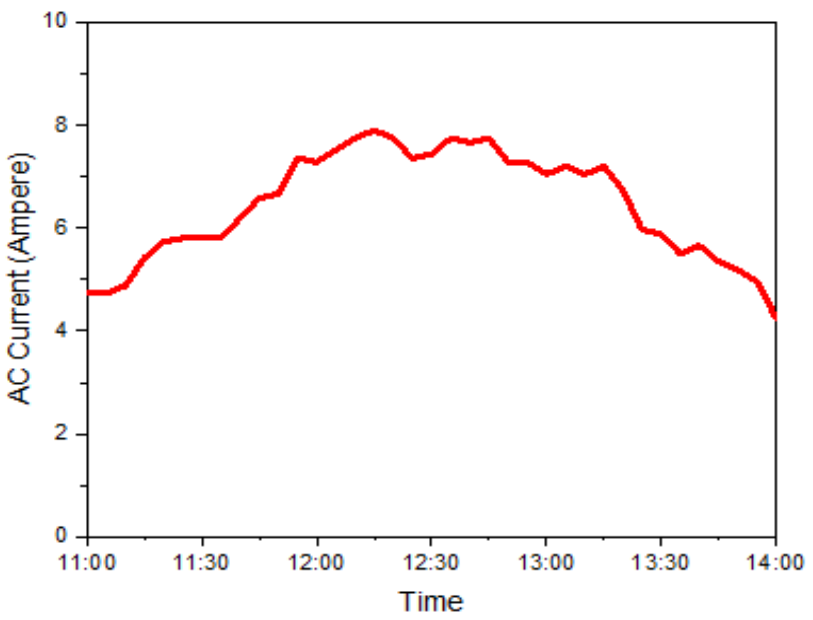

Fig 12. DC current measurement with graphic display

\section{H. DC Power Output Data}

DC power peak load data taken for 3 hours, for a peak power of 972.56 Watt in the time interval 11 am to $2.00 \mathrm{pm}$.

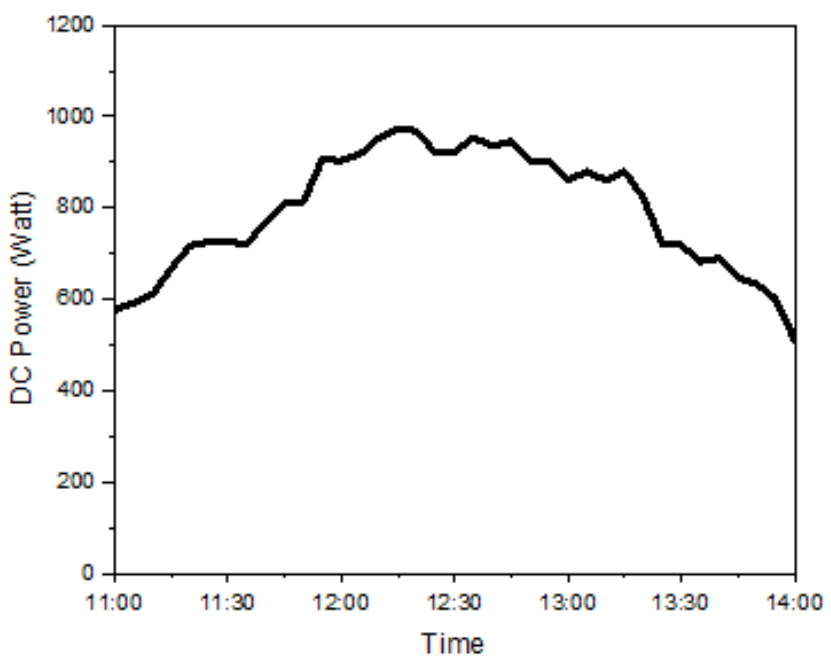

Fig 13. DC Power Measurement with graphic display

\section{CONCLUSION}

The development of a PV Power Plant system is very much needed when heading towards the industrial era 4.0, this cannot be separated from the references made by previous research. In the installation of Rooftop PV, there are many things that must be considered so that the conversion performance produced by PV can be maximized. The DHT11 sensor can only measure the surface temperature of the panel but cannot measure the air temperature, this affects the temperature rating which over time on data acquisition is detected that the temperature continues to increase. The results of the Roof PV measurement when the sun is bright at 11.00 am to $2.00 \mathrm{pm}$ in the West Sumatra area with a PV capacity of $1.25 \mathrm{kWp}$, the peak DC power generated is $972.56 \mathrm{~W}$ at intervals of 3 hours.

\section{ACKNOWLEDGMENT}

The author would like to thank the Ministry of Research, Technology and Higher Education's DRPM for its support in research through the Postgraduate Team Research scheme.

\section{REFERENCES}

[1] A. J. Veldhuis and A. H. M. E. Reinders, "Reviewing the potential and cost-effectiveness of off-grid PV systems in Indonesia on a provincial level," Renewable and Sustainable Energy Reviews, vol. 52. 2015.

[2] A. J. Veldhuis and A. H. M. E. Reinders, "Reviewing the potential and cost-effectiveness of grid-connected solar PV in Indonesia on a provincial level," Renewable and Sustainable Energy Reviews, vol. 27. 2013.

[3] K. B. Adam, M. Ramdhani, and E. Suhartono, "A technical and economic analysis of solar PV with local tariff policy in Indonesia," in IOP Conference Series: Materials Science and Engineering, 2020, vol. 830 , no. 3 .

[4] H. E. Colak, T. Memisoglu, and Y. Gercek, "Optimal site selection for solar photovoltaic (PV) power plants using GIS and AHP: A case study of Malatya Province, Turkey,” Renew. Energy, vol. 149, 2020.

[5] P. Unahalekhaka and P. Sripakarach, "Reduction of Reverse Power Flow Using the Appropriate Size and Installation Position of a BESS for a PV Power Plant," IEEE Access, vol. 8, 2020.

[6] M. Järvelä, K. Lappalainen, and S. Valkealahti, "Characteristics of the cloud enhancement phenomenon and PV power plants," Sol. Energy, vol. 196, 2020.

[7] P. H. A. Veríssimo, R. A. Campos, M. V. Guarnieri, J. P. A. Veríssimo, L. R. do Nascimento, and R. Rüther, "Area and LCOE 
considerations in utility-scale, single-axis tracking PV power plant topology optimization," Sol. Energy, vol. 211, 2020.

[8] A. Sharma, S. Pandey, and M. Kolhe, "Global review of policies \& guidelines for recycling of solar pv modules," International Journal of Smart Grid and Clean Energy, vol. 8, no. 5. 2019.

[9] A. S. D. Rai, K. Shratriya, and A. Kurchania, "Solar panel cleaning device," Int. J. Recent Technol. Eng., vol. 8, no. 3, 2019.

[10] S. Syafii, N. Novizon, W. Wati, and D. Juliandri, "Feasibility Study of Rooftop Grid Connected PV System for Peak Load Reduction," Proceeding Electr. Eng. Comput. Sci. Informatics, vol. 5, no. 1, 2018.

[11] H. Satria, "Pengukuran Parameter Sistem PV Power Plant Tersambung Pada Jaringan Tenaga Listrik Berdasarkan Real Time Clock," Setrum Sist. Kendali-Tenaga-elektronika-telekomunikasikomputer, vol. 9, no. 2, 2020.

[12] Syafii, Wati, Novizon, and D. Juliandri, "Economic feasibility study of rooftop grid connected PV system for peak load reduction," in International Conference on Electrical Engineering, Computer Science and Informatics (EECSI), 2018, vol. 2018-October, doi: 10.1109/EECSI.2018.8752957.

[13] B. Uzum, A. Onen, H. M. Hasanien, and S. M. Muyeen, "Rooftop solar pv penetration impacts on distribution network and further growth factors-a comprehensive review," Electronics (Switzerland), vol. 10 , no. 1. 2021.

[14] S. Sathiracheewin, P. Sripadungtham, and S. Kamuang, "Performance analysis of grid-connected PV Rooftop, at Sakon Nakhon Province,
Thailand," Adv. Sci. Technol. Eng. Syst., vol. 5, no. 4, 2020.

[15] D. Wang et al., "A method for evaluating both shading and power generation effects of rooftop solar PV panels for different climate zones of China," Sol. Energy, vol. 205, 2020.

[16] Y. N. Chanchangi, A. Ghosh, S. Sundaram, and T. K. Mallick, "Dust and PV Performance in Nigeria: A review," Renewable and Sustainable Energy Reviews, vol. 121. 2020.

[17] B. Plangklang, N. Thanomsat, and T. Phuksamak, "A verification analysis of power quality and energy yield of a large scale PV rooftop," Energy Reports, vol. 2, 2016.

[18] Syafii and R. Nazir, "Performance and energy saving analysis of grid connected photovoltaic in West Sumatera," Int. J. Power Electron. Drive Syst., vol. 7, no. 4, 2016, doi: 10.11591/ijpeds.v7i4.pp13481354.

[19] V. Durković and Ž. Đurišić, "Extended model for irradiation suitable for large bifacial PV power plants," Sol. Energy, vol. 191, 2019.

[20] Z. Usman, J. Tah, H. Abanda, and C. Nche, "A critical appraisal of pv-systems' performance," Buildings, vol. 10, no. 11. 2020.

[21] S. UTAMI, "Optimal Design Of Renewable Energy Systemusing Genetic Algorithm Case Study In Parangtritis," ELKOMIKA J. Tek. Energi Elektr. Tek. Telekomun. Tek. Elektron., vol. 4, no. 2, 2018.

[22] Q. M. Aish, "Temperature Effect on Photovoltaic Modules Power Drop," Journal Al-Khwarizmi Engineering Journal, vol. 11, no. 2. 2015. 